\title{
Immigration and the National Narrative: Rethinking Corporatism in Singapore
}

\author{
NORMAN VASU AND DAMIEN D. CHEONG
}

\begin{abstract}
This article argues that the corporatist narrative of governance in Singapore is losing narrative rationality due primarily to large-scale immigration to Singapore. The real or perceived threat from such immigrants has galvanized Singaporeans from different ethnic groups such that a strong Singaporean identity has emerged. As a result, the once strict artificial differences required for the corporatist narrative to be believable, that is, its narrative rationality, are being gradually eroded. The People's Action Party (PAP) will have to either repair the narrative rationality of corporatism or develop an alternative one that is more relevant in order to continue its narrative dominance of the political space in Singapore.
\end{abstract}

Keywords: Singapore, governance, immigration, corporatism, narrative

\section{Introduction}

The existing national narrative of governance portrays Singapore as a racially and religiously divided society where harmony has prevailed due to the actions of a determined and neutral government. This narrative of governance is customarily described in the social sciences as corporatism, and it denotes a form of governance in which the state is exclusively responsible for legitimating and enfranchising group and individual participation in public affairs, while also being responsible for managing the harmonious interaction between such groups and individuals. This has been a key tenet of the 'Singapore Story', ${ }^{1}$ which holds that despite communal tensions in the 1950s and 1960s, Singapore, under the stewardship of the People's Action Party (PAP) has successfully created and maintained inter-communal harmony through its policies. ${ }^{2} \mathrm{As}$ such, corporatism in Singapore is operationalized through 'governing through difference', whereby citizens are segmented through artificial differences in order to discipline the manner in which the political and social landscape is understood and managed by the political elites. 
This article critically analyses the corporatist narrative of governance in Singapore and argues that it is losing narrative rationality. Narrative rationality, that is, a narrative's 'believability', is being eroded through large-scale immigration to Singapore. The influx of immigrants reduces the strict artificial differences required for the corporatist narrative to be relevant. The loss of narrative rationality is significant as it could jeopardize continued rule by the PAP. The PAP will therefore either have to repair the narrative rationality of corporatism or seek an alternative narrative that is more relevant in order to maintain the party's narrative dominance of the political space in Singapore in the long run.

The article is divided into three broad sections. In the first section, corporatism as a form of governance as well as a narrative is discussed. While 'corporatism' has been used predominantly to describe a particular strategy of economic management by the state, this article employs the term in its previous form where it is used to denote the attempt to shift Gesellschaft communities to the more harmonious Gemeinschaft variant (Schmitter 1974; Wiarda 1981; Williamson 1989). In contrast to traditional liberal politics, where politics is organized in the interest of individuals or classes, corporatist politics in Singapore is premised upon a narrative where enlightened elites manage a fractious racial and religious mass/mess that makes up Singaporean society. With this type of governance, continued rule by elites is legitimized through the maintenance of social harmony.

In the second section, the impact of large-scale immigration on the corporatist narrative is analysed. Through the use of Walter Fisher's narrative paradigm, this section will demonstrate how the narrative rationality of governance in Singapore can be critically assessed through its narrative coherence and narrative fidelity. Through the employment of Fisher's notion of testing narrative rationality, the authors argue that Singapore's corporatist narrative may be scuttled by an alteration to empirical reality in Singapore, as the racial divisions that corporatism seeks to manage are becoming increasingly indistinct. As such, the narrative of governance may be less convincing than it once was - a situation that would have significant bearing on the way Singapore is governed. The final section briefly examines how the PAP is addressing the issue and suggests some alternative approaches for consideration. 


\section{Corporatism in Singapore}

Singapore has been described as a 'paternalist state', a 'developmental state', a 'semi-authoritarian state', an 'electoral authoritarian regime' and a 'corporatist state' by many scholars and analysts (Chua 1995; Low 2001; Case 2011; Fukuyama 1995; Means 1998; Vasu 2012). Out of these various characterizations, corporatism is arguably more accurate as it takes into account the foundational role multiculturalism plays in governance in Singapore. Paternalism, semi-authoritarianism and electoral authoritarianism focus mainly on the authority of the state in governance. Paternalism is, by and large, interested in the relationship between the state and its people en masse, while semi-authoritarianism and electoral authoritarianism are generally concerned with the 'less than democratic tactics' (Chua 1995: 204) employed by the government to control dissent and maintain authoritarian rule by 'adorning it with greater legitimation' (Case 2011: xiv). As for the concept of the developmental state, its primary focus, when applied to Singapore, is the role of government (and government-linked corporations) in advancing economic growth. Hence, these characterizations do not take into account the important role played by the determined fostering of inter-communal difference to support a particular form of governance.

It is important here to highlight that while the contemporary use of corporatism as a concept has predominately been to describe a particular strategy of economic management by the state, this article employs the term in its older, original form. In its traditional form, corporatism describes the attempt to transform society from one where society is maintained by individual self-interest (Gesellschaft) to one where societal mores and beliefs restrain individuals (Gemeinschaft). Hence, the term is deployed here to capture the attempt to shift Gesellschaft communities to the more harmonious Gemeinschaft variant. ${ }^{3}$

Corporatism, while a mode of governance, can be understood as a narrative of governance as well. Hence, the mode of governance (corporatism) and the narrative of governance (the story that makes corporatism intelligible) are two sides of the same coin. Expressed differently, for governance in such a form to take place, it requires a narrative for this form of governance to be both intelligible and supported. In the case of corporatism, a society has to believe a narrative that it is indeed plagued by Gesellschaft disunity, and therefore requires enlightened steerage to arrive at Gemeinschaft unity. Understanding the intimate relationship between modes of governance and narratives of governance is not new. 
It is commonly acknowledged that a useful technique employed to create a common purpose among members of a society is the development of a narrative. Narratives carry much potency 'because they possess an internal coherence for their intended audiences that connects them to grand, deeply culturally embedded views of history...[which they can]...readily understand, identify with, or feel little need to question' (Halverson, Goodall and Corman 2011: 13). For this reason narratives have been used for political purposes such as generating social cohesiveness within a newly established state or mobilizing support for a leader or political party against a real or perceived threat. As Ernest Koh observes:

There is a simple arc to all national narratives. As creation stories, they occlude, submerging heterogeneity and reducing the reality of multifarious, plural pasts into fictitious, common histories. They tell of heroes and leaders, convey important decisions and moments, and create legitimacy for the empowered. This is particularly true for postcolonial societies, where divided pre-colonial loyalties need to be reconfigured and reconciled with new postcolonial allegiances. (Koh 2010: 1)

Existing research and scholarship have demonstrated that 'stories are universally basic to conversation and meaning making', and 'humans appear to have a readiness, from the beginning of life, to hear and understand stories' (see, for instance Read and Miller 1995). According to narrative psychology, stories are the most efficient and natural way to communicate, especially when communicating about others (see, for example, Bruner quoted in Dautenhahn 2002: 103). Humans' penchant for stories and storytelling may be, arguably, due to their biology that has evolved over time (Dautenhahn 2002). Notwithstanding, communicating through storytelling, that is, the act of narration, is a highly effective and efficient way to enable human beings to: 1) make sense of the events of everyday life; 2) connect new information to old existing information; and 3) justify their resulting actions (Halverson et al. 2011: 15).

In accordance with the corporatist narrative, state-society relations are contrary to the liberal tradition whereby society and its groups legitimize the power of the state. Instead, it is the state that legitimizes and enfranchises group and individual participation in public affairs. As Simon Schwartzman has argued:

The ideal of a harmonious, well-regulated, non-conflictive society, based on moral principles and well-defined norms which are issued and maintained by the public authority, the state... There should be some intragroup autonomy and self-regulation, but the very existence of groups and their relationships with each other are granted and regulated by the state... [emphasis added]. (Schwartzman 1977: 91) 
In addition, David Brown has also argued that:

The essence of corporatism is the attempt to reconcile two apparently antithetical ideas: the image of society and the state as comprising a natural organic gemeinschaft community; and the image of society as an unintegrated aggregation of disparate groups. The two ideas are reconciled in the view of politics as state management... The corporatist characterization of the state thus implies... the state is dominated by bureaucrats and technocrats who are depicted as acting according to the imperatives of statehood. (Brown 1997: 70)

These state elites are viewed as experts and professionals in their various fields, hence, within such a model, 'the state is perceived as autonomous of society, as the neutral agency seeking the stability, unity and development of the society through efficient management' (Brown 1997: 70). By adopting a corporatist view of state-society relations, communal differences are considered to be problematic as there is no natural communal cohesion. With no natural cohesion, society has to be held together and developed artificially by a strong interventionist state, which results in a situation whereby the state practices state-induced collaboration to co-opt society's various fractious groups in order to achieve goals that are beneficial to all (Panitch 1980; Choi 1999). As former Deputy Prime Minister Wong Kan Seng once remarked: 'Social harmony is a valuable capital on which we can safeguard Singapore's future success. ${ }^{14}$ Expressed alternatively, the narrative and form of governance in Singapore are premised upon an ontological reality of an otherwise divided populace managed by an enlightened ruling elite in order to achieve economic success.

\section{Multiracialism: Corporatism's Foundation}

\section{Historical Underpinnings}

The concept of multiracialism was adopted by Singapore's political elites as the bedrock of Singapore's official multicultural policy soon after the nation's founding in 1965. For administrative purposes, the local population was classified into four groups: Chinese, Malay, Indian and Others (CMIO). Arguably, the adoption of multiracialism prepared the ground for the corporatist model to thrive. Admittedly, some observers have argued that while it would certainly be overly cynical to maintain that the Singapore government had intended to enlist race to support corporatism from the point of independence, there is, nevertheless, 
evidence to suggest that the concept of multiculturalism in the form of multiracialism as adopted by Singapore upon independence, has become integral to the development of corporatism (Chua 2007, 2003; Brown 1997: 78).

The categorization of the local population along racial lines, the socalled CMIO (Chinese, Malay, Indian, Other) model, is largely a remnant of British colonial rule when the classification was employed for the purpose of census taking. It reflects the three major places of origin of immigrant groups that began to inhabit the city-state when the British first set up a trading post there, namely China, the neighbouring region of Southeast Asia and South Asians from British India. Significantly, the model ignores the intra-racial diversity found within these three constructed groups, and instead treats each as a more or less homogenous entity. The group of Chinese immigrants quickly formed the majority of newcomers, and by the 1960s already comprised 65 per cent of the population. When Singapore gained political independence, the national demographic distribution stood at 75 per cent ethnic Chinese, 17 per cent Malays, and 7 per cent Indians. The remaining 1 per cent of the population fell under the category 'Others', which refers to individuals whose ethnic background was deemed incompatible with the official categories of Chinese, Malay or Indian. Eurasians and/or Jews for example, were included in this fourth category. As exemplified by the CMIO model, the Singaporean approach to multiculturalism - that is, the manner in which Singapore understands communal differences and manages them - is based on the assumption that the nation's population is composed of individuals with only one unchanging racial identity. Strict bureaucratic separation of the groups through various government policies ensures that boundaries between the different racial categories remain intact.

A primary instrument for this purpose has traditionally been the determination of a citizen's race following his/her paternal line, and the subsequent recording of the ascribed racial category on one's birth certificate and the National Registration Identity Card (NRIC). Until very recently, the possibility of altering the ascribed racial identity was very limited at best. Only in 2010 did the government introduce a bureaucratic compromise that permitted Singaporean children born to parents of different races to choose a hyphenated race option for their identification papers. Nevertheless, while the practice of racial compartmentalization may have been liberalized somewhat, it is still mandatory for parents to indicate a 'prime' race for their children for administrative purposes. ${ }^{5}$ 
Besides the preservation of the racial categories through administrative diktat, the state has also essentialized the inter-racial cultural identities through Singaporean multiculturalism as each race is invested with cultural traits, such as language and dress, unique to them. The simplification of these cultural traits is striking as is the apparent assumption that these examples of cultural heritage can be passed down through the generations and remain largely unaltered. To arrive at this sub-group division, racial categories were created by 'a discursive practice that reduces and "homogenises" ethnic, linguistic and religious differences within each category itself' (Chua 2006). Intra-racial differences within these inherently heterogeneous groups had to make way for a simplified commonality, thereby allowing for the construction of the broad CMIO categories.

Ignoring the linguistic diversity among the group of immigrants that hailed from a diverse array of Chinese provinces, Mandarin was adopted as the common language of instruction in education and as the language of the national media in order to mould a homogenous racial category of 'Chinese'. The imposition of Mandarin was designed to unite and bind this segment of society, and in furtherance of this objective, it was decided that other Chinese languages such as Hokkien, Hakka and Cantonese had to be removed from the public space. A similar approach of enforced homogenization was adopted in reference to the other racial groups. For example, Malay was chosen as the single language to be used in public discourse to unite a diverse array of indigenous communities composed of communities such as the Javanese, Minangkabau, Baewanese and Achehnese, under the catchall race of 'Malay'. Geography became the defining criterion for the classification of the racial group 'Indian', with anyone whose ancestors originated from South Asia falling in this third category. Language, religion and geography were thus employed in varying degrees to construct distinguishable entities based on magnified differences between the three major racial categories under the CMIO model.

As Singapore began to grow as a nation, additional cultural markers including food, dress and/or dance were introduced to further cement the intra-racial ties within each of these constructed categories, while at the same time deepening inter-racial differences. A very vivid example of what may be referred to as the essentialization of race through the aforementioned three markers is the annual celebration of 'Racial Harmony Day' in Singapore's schools on the 21st of July. On this day, students are made to dress, eat and dance in the 'traditional' manner 
of their ascribed culture in an effort to, as maintained by the Ministry of Education,

Remind our pupils that social division costs us dearly and that race and religion are potential fault-lines in Singapore society. It is a day for schools to reflect on, and celebrate our success as a harmonious nation and society built on a rich diversity of cultures and heritages. ${ }^{6}$

In short, through the creation of racial categories and the investment of the categories with 'unique' traits, an important criterion for corporatism was established. Through the CMIO model, Singaporean society could be portrayed as suffering from Gesellschaft disunity-there are inter-communal differences within the Singaporean society requiring a neutral agency both to bring stability and to extract the best out of a fractious people.

The lynchpin role played by managed social harmony to secure economic progress is continually stressed by the Singaporean government. This is of course unsurprising as the internal logic of the virtuous/vicious cycle is buttressed by continued management for economic return. As the Ministry of Foreign Affairs noted, 'maintaining racial and religious harmony and treating minorities fairly is not just the morally correct thing to do. It is a political, economic and even foreign policy imperative for our continued survival and prosperity. ${ }^{7}$ Moreover, 'better understanding of each community's aspirations leads to tolerance and racial harmony in our society, which is a fundamental pillar of Singapore's stability and consequently its economic progress. ${ }^{18}$

The reinforcement of racial divisions constructed by multiculturalism in Singapore constitutes a virtuous/vicious cycle. With the racial differences constructed and immutable, professional elites work selflessly to bring harmony between the races; the races enjoy the harmony brought about by such management; harmony provides the stability for economic growth; continued harmony and economic development is thus dependent upon continued management. The cycle and the narrative, along with everyone's place in it, cannot be recast because, without proper stewardship, Gesellschaft disorder will prevail over Gemeinschaft order.

\section{Sustaining Multiracialism}

While corporatism's bedrock has been multiracialism, governing through difference, especially for political, economic and social issues, perpetuates the virtuous/vicious cycle by continually entrenching racial differences through a lived reality. Similar to social boundary making, 
as depicted by Fredrik Barth (1969), governing through race for political, economic and social issues sustains the racial boundaries constructed by multiculturalism in Singapore as they are absorbed by the force of habit, repetition and ritual. As David Brown notes:

In the case of Singapore, the corporatist tendency has extended to incorporate the ethnic dimension to such an extent that the state elites have developed a marked predisposition to depict and to organize Singaporean society along primarily ethnic lines, even for the discussion of economic, political and social issues which do not relate directly to the ethnic realm of linguistic, religious or racial matters. (Brown 1997: 77)

Government policies in three key spheres of Singapore life aid in the sustenance of the corporatist narrative of governance: 1) politically, the institutionalization of race in the electoral process via the Group Representation Constituencies (GRC); 2) economically, socio-economic assistance is distributed through race-based lines; and 3) socially, citizens are encouraged through education to maintain their 'unique' cultural traits, while the sale of public housing is based on racial quotas. This management of group differences through institutional recognition of racial difference in the public sphere leaves little doubt that political elites in Singapore are determined to maintain the unity they have achieved through managed disunity in order to perpetuate the virtuous/vicious corporatist cycle, and everyone's place in it. Somewhat ironically, the government seeks legitimization largely with reference to its ability to successfully maintain the social harmony necessary for political stability and economic growth despite Singaporean racial differences - even though it played a decisive role in magnifying, or at least constructing, those differences in the first place.

With regard to the institutionalization of corporatism facilitated by multiculturalism through the political process, in 1988, GRCs were introduced to the electoral process. GRCs are multi-member constituencies contested by teams of candidates. In each GRC, at least one candidate must be from a minority race: Malay, Indian or Others (Mutalib 2002: 665). According to Article 8A of the Parliamentary Elections Act (c. 218), the purpose of the GRC is 'to ensure the representation in Parliament of Members from the Malay, Indian and other minority communities.' The logic of this introduction as explained by a Parliamentary Select Committee was that the system would 'preserve our fragile, multi-racial fabric' and 'entrench the multi-racial character of our Parliament. ${ }^{9}$ Within this system, the number of non-Chinese parliamentary seats is calibrated to be approximately 25 per cent of 
the number of seats in Parliament, a proportional representation of the approximately 25 per cent non-Chinese population.

The GRC system continues to face significant criticism. Critics condemn what appears to be a substantial competitive advantage for the PAP as the GRC system places de facto limits on the number of constituencies the opposition parties can contest in an election due to their substantially smaller candidate pool. In addition, the GRC system has also been described as a tool for the ruling party to safeguard its dominance in Parliament rather than fulfilling the function of securing a multiracial Parliament (Mutalib 2002: 665-667). The GRC system can arguably also be used to secure the continued corporatist model and narrative of governance in Singapore. It does so by firmly rooting the electoral process in the racial differences that have been created by multiracialism. Furthermore, the system serves as a reminder for citizens of the racial category they belong to while also stressing how the differences between the races can lead to political tension if not managed well. Consequently, through the GRCs, the necessary communal division for corporatism to be practiced is sustained.

Another key tool in the institutionalization of corporatist governance in the economic sphere has been the establishment by the government of welfare organizations dedicated to the well-being of members of specific racial groups. The initial step in this direction was taken in 1982 with the creation of the Council for the Education of Muslim Children (MENDAKI). MENDAKI is tasked with finding solutions to major social problems in the Muslim community including drug abuse, teenage pregnancy and educational under-achievement. As almost 99 per cent of Singapore's ethnic Malays belong to the Muslim faith, MENDAKI is considered a Malay welfare organization. ${ }^{10}$ The establishment of MENDAKI signalled the beginning of the creation of similar organizations responsible for the welfare of the remaining racial groups with the Singaporean Indian Development Association (SINDA) and the Chinese Development Assistance Council (CDAC) emerging shortly thereafter. A portion of these organizations' finances come from the monthly contributions of its respective members, and the willingness of members to contribute to the fund is taken for granted. The possibility to opt-out does exist, but requires the individual to submit a formal written request. The existence of these groups further nourishes the corporatist governance model and narrative because through practicing a form of racialized welfare, citizens continually imbibe the government's understanding of racial divisions, thereupon further legitimizing corporatism and the virtuous/vicious cycle. 
Beyond the political and economic spheres, education and housing policies are also important elements that reinforce racial differences in the social sphere. While the language of instruction in Singapore's schools is English, the 1980s saw the introduction of the mother-tongue policy, which obligates each student to study a language of his/her ascribed race. Chinese students learn Mandarin while their Malay counterparts learn Malay; recognizing the greater linguistic variation within South Asia, Indians learn for example, Tamil, Bengali, Gujarati, Hindi, Punjabi or Urdu. However, as hypothesized in Barth's theory on social boundary making, mother-tongue education goes beyond the mere learning of a language by equipping children with the tools to better understand their cultural 'heritage' as well. Mother-tongue education may therefore also be understood as an important instrument to produce new generations of racially sensitized citizens. A landmark review of education published in 1979 described the purpose of the mother-tongue policy as ensuring that 'no child should leave school after 9 years without having the "soft-ware" of his culture programmed into his subconscious. ${ }^{11}$

Besides education, Singapore's housing policy further amplifies racial differences with the imposition of racial quotas in 1989 on the sale of public housing. The official justification for racial quotas remains the expressed desire to prevent the emergence of racial enclaves in a country where approximately 83 per cent of the population live in governmentbuilt housing estates. Thus, having created racial divisions in the public sphere, the Singaporean government has subsequently been forced to impinge upon the housing market to ensure the constructed racial groups do not constellate together. With the majority of Singaporeans living in government-built housing, even the seemingly innocuous act of purchasing one's home becomes an activity to remind citizens of the manner in which their society is organized.

Beyond the absorption of race through these various policies, the policies also play a further role in reinforcing the corporatist narrative. By implementing multicultural policies, the Singapore government is ironically able to bolster its position as neutral arbiter between the fractious mass/mess. These policies permit the government to claim intercommunal harmony as a product of its continued efforts, strengthening the government's position as harmony-maker par excellence. Moreover, such policies also temper the virtuous/vicious cycle and everyone's place and role in it. The cycle then goes as follows: elites are continually actively ensuring inter-communal harmony; inter-communal harmony 
has allowed for economic progress; the masses have profited from this harmony; and the cycle continues. Moreover, within this cycle, the corporatist narrative remains effectively true, unquestionable and believable.

\section{Evaluating the Existing Corporatist Narrative}

There is a large body of empirical, survey-based research that has demonstrated that feelings of Singaporean-ness are indeed very prevalent in the city-state, a situation that does not bode well for a system founded on the management of separate racial groups. One such early survey was the Singapore National Identity Survey (SNIS) in 1976 that found 90 per cent of respondents accepting the label of Singaporeans; 88 per cent affirming strongly that they are Singaporean; and 75 per cent preferring to be referred to as Singaporean over their race (MacDougall 1976: 514). Corroborating the findings of this early survey, a Ministry of Community Development and Sports (MCDS) survey on the Social Attitudes of Singaporeans (SAS) in 2001 found 97 per cent of respondents proud to be Singaporean and 98 per cent considered Singapore to be their home (Chan 2002: 11). Moreover, the study found 'high endorsement of national identity generalised across the different demographic groups (i.e. race, religion, gender, age, education and household income groups)' (Chan 2002: 11). Besides the government's own findings, an Institute of Policy Studies (IPS) survey of Singaporeans in 2002 concluded that 78 per cent of Singaporeans regarded themselves more as 'Singaporean' than as 'Chinese' or 'Malay' or 'Indian' (i.e. their prescribed CMIO race) (Ooi, Tan and Soh 2002: 3). The survey also revealed that the corporatist premise of having enlightened managers to oversee fractious groups was becoming redundant since inter-ethnic relations were shown to be sturdy with 'strong progress since 1990 in building national identity shared by our multi-ethnic society' (Ooi, Tan and Soh 2002: 7). Another survey that further validated previous findings was conducted by the S. Rajaratnam School of International Studies (Chin and Vasu 2007). Titled The Ties that Bind and Blind, the survey found inter-racial and inter-religious relations in Singapore to be robust with the concepts of race and religion having little bearing on Singaporean interaction in the economic, security, political and social domains of the public sphere. Finally, in a longitudinal survey on the National Orientations of Singaporeans (NOS), the study ascertained that over the course of four surveys from 1993 through 2010, feelings 
of Singaporean-ness remained consistently high (Tan and Koh 2010). In this study's latest iteration, 97 per cent of respondents were 'proud to be Singaporeans' (Tan and Koh 2010).

In light of the empirical evidence cited above, Singaporean commonality does appear to be resilient contrary to the government's seeming attempt to carve racial differences into the social fabric of Singapore. Moreover, the shedding of racial communal differences may in fact accelerate over time, due in part to the shared experience of facing largescale immigration into Singapore over the past 20 years. Since the late 1980s, the Singapore government has consistently been pro-immigration for four main reasons: 1 ) the desire to expand the talent pool available for industry; 2) to remain competitive with other countries with deeper pools of cheap labour; 3 ) to supplement the low total fertility rate that is currently well below replacement levels; and 4) to maintain the racial demographic at the level found at independence. ${ }^{12}$

With the world coming to Singapore to work and live, Singaporeans appear to be awakening to a newfound commonality among themselves in the face of an influx of new migrants. This inter-communal bond generated through interaction and indeed competition with 'foreigners' amplifies the 'us' and 'them' dichotomy, further strengthening the Singaporean identity. As Janadas Devan, former associate editor of the Straits Times observed:

We must take the task of integrating foreigners, 'new' Singaporeans, as seriously as we took racial integration or religious harmony. Indeed, the local-foreign divide may pose a more serious risk to our social stability now than racial differences. The differences within each race today - especially among Chinese and Indians - seem to be greater than the differences between the races. That is so chiefly because of the large inflow of ethnic Chinese from the mainland and ethnic Indians from the subcontinent into Singapore over the past decade or so. ${ }^{13}$

The number of immigrants entering the workforce is significant. Between 2001 and 2006, there was a marked increase in numbers, from 670,000 to 756,300 , and as it stands, foreigners comprise approximately 30 per cent of Singapore's workforce. ${ }^{14}$ All three forms of immigrationgastarbeiter (aka blue-collar workers), permanent resident (PR) and the new citizen-expose Singaporeans to the 'Other', which has resulted in foreign/local tensions and the enhancement of Singaporean-ness. For example, gastarbeiter in Singapore, which is a euphemism for 'foreign worker', as opposed to either 'foreign talent' or 'global talent' (both of which refer to more highly-skilled middle and upper management 
workers), have contributed to tensions as well as a heightened sense of Singaporean-ness by their presence and activities. ${ }^{15}$ For instance, their gatherings at and near housing estates during the weekend has caused conflicts with Singaporeans, which have on occasion resulted in violence. ${ }^{16}$ Residents of some housing estates have erected steel barricades around their housing block to keep workers out, while others have organized resident patrols to prevent loitering. The stark symbolism of barricades and patrols should not be overlooked. It is clear that these actions are an illustration of how 'we' have to protect ourselves from a very different 'them'.

There is also tension between new citizens and old ones that further strengthens Singaporean-ness. This divide has become especially noticeable within the sporting arena where foreigners are naturalized in order to make Singapore more competitive on the international sporting stage. ${ }^{17}$ Labelled the Foreign Sports Talent (FST) scheme, and introduced in 1993 to fast-track promising foreign athletes to Singapore citizenship, this scheme has been relatively successful as it has enabled Singapore to win its first Olympic medals in 48 years. However, public reaction to this achievement has not been entirely positive, with critics lamenting that the athletes were not actually true-blue Singaporeans. As reported in the local media: 'Nowhere else [in the world], it seems, do you witness such disenchantment simply because the athletes bringing home the medals aren't native. ${ }^{18}$ The recent 2012 Olympics in London reignited this debate when the women's table tennis team won two bronze medals. As the Straits Times reported, while China-born Feng Tian-wei's bronze medal was the country's first individual Olympic medal in 52 years, 77 per cent of those who responded to an online poll 'were "not proud" of a "foreign import" winning an Olympic medal.' This is despite the fact that Feng had been granted Singapore citizenship in 2008. ${ }^{19}$ This native/naturalized tension has not been limited to the international sporting stage. For example, in an inter-school badminton competition, traditional school rivalry was put aside when one school entered a team comprised mainly of foreigners. ${ }^{20}$

Beyond the world of sports, the new/old citizen tension has also spilled over into domestic politics where fears have been expressed about relatively new citizens becoming office holders in the PAP. ${ }^{21}$ Moreover, in the 2011 parliamentary elections, this us/them divide became a major issue in the election hustings. During the campaign, the PAP's organizing secretary, $\mathrm{Ng}$ Eng Hen, questioned the Singaporean-ness of Chen Show Mao, the Workers' Party candidate for the GRC of Aljunied, as he had 
lived abroad for over 30 years. ${ }^{22}$ Likewise, the Workers' Party highlighted how Janil Puthucheary, a PAP candidate for the GRC of Pasir Ris, was a 'new' citizen, having recently adopted Singaporean citizenship in 2008, and not serving what is commonly considered the sine qua non rite of passage of all male Singaporeans: national service. ${ }^{23}$ The tension with regard to these issues is very revealing. It emphasizes the presence of inter-communal cross-race bonds between Singaporeans fearful of the 'Other' infiltrating domestic politics.

Thus, if the empirical data is taken together with the emerging evidence found in the lived experience of housing, sports and politics, the global meeting the local has unintentionally stirred an embryonic Singaporean-ness that then threatens the entire virtuous/vicious cycle found within the closed corporatist system. As such, experienced reality has drifted from the reality that the corporatist narrative seeks to describe, arguably making the narrative lose rationality (i.e. believability) with its audience as well as possibly eroding corporatism as a form of governance.

\section{Losing Narrative Rationality}

If we concede that fabricated communal difference supports corporatist governance, and that corporatism can also be understood as a narrative of governance, the question remains whether it is possible to assess the narrative's credibility among the masses it requires for support. It is here that Fisher's narrative paradigm (Fisher 1987: 57-78), which holds that humans make decisions and make sense of the world through a narrative logic rather than a rational logic, may be employed. The differences between the two forms of logic are expressed in Table 1 (Dainton and Zelly 2005).

Hence, for Fisher, people are persuaded and influenced to action based on good reason derived from factors such as their culture, history and experience, and not by a 'neutral' rational form of decision making (Fisher 1987: 105-121). As humans make sense of the world through stories, rather than a strict form of rationalism, all discourse-spanning a scientific treatise to a religious text to a political ideology - can be understood, analysed and judged via a two-pronged analytic fork. To be judged good, believable and reasonable, a narrative has to satisfy the first prong of narrative coherence and the second prong of narrative fidelity.

According to Fisher, narrative coherence may be understood as the integrity of a story's structure, or alternatively, how it 'hangs together' 
TABLE 1: Comparison between Rational World and Narrative Paradigms

\begin{tabular}{|l|l|}
\hline The Rational World Paradigm & The Narrative Paradigm \\
\hline People are essentially rational & People are essentially storytellers \\
\hline People make decisions based on arguments & People make decisions based on good reasons \\
\hline $\begin{array}{l}\text { The communicative situation determines the } \\
\text { course of our argument }\end{array}$ & $\begin{array}{l}\text { History, biography, culture, and character deter- } \\
\text { mine what we consider good reasons }\end{array}$ \\
\hline $\begin{array}{l}\text { Rationality is determined by how much we } \\
\text { know and how well we argue }\end{array}$ & $\begin{array}{l}\text { Narrative rationality is determined by the coher- } \\
\text { ence and fidelity of our stories }\end{array}$ \\
\hline $\begin{array}{l}\text { The world is a set of logical puzzles that we } \\
\text { can solve through rational analysis }\end{array}$ & $\begin{array}{l}\text { The world is a set of stories from which we choose, } \\
\text { and constantly re-create, our lives }\end{array}$ \\
\hline
\end{tabular}

Source: Dainton and Zelly, 2005: 123.

(Fisher 1987: 47-49). In order to be coherent, a story has to possess a consistent story arc, there should be enough detail in the story, the characters have to behave in a manner considered by the audience as reliable and, finally, there should be no unrealistic surprises or alternative interpretations for the audience. A narrative can be judged coherent as individuals have had experience with other stories and thus have developed measurement standards over time.

The second prong of narrative validity is fidelity. Here, 'the degree to which a narrative is consonant with the already established pantheon of narratives that describe our view of the world and our place in it' is evaluated (Schrag 1991: 314). For Fisher, the best narratives are ones that fulfil the four dimensions of fidelity where the narrative is: '1) true to and consistent with what we think we know and what we value; 2) appropriate to whatever decision is pending; 3) promising in effects for ourselves and others; and 4) consistent with what we believe is an ideal basis for conduct' (Fisher 1987: 194). In short, narratives that demonstrate 'the most compelling warrants for behaviour or belief, are those with which [individuals] most closely identify', and hence, these will assume a higher position in the individual's hierarchy of narratives, which he/she regards as meaningful (Schrag 1991: 134).

Employing Fisher's analytic fork, it is possible to assess the narrative of corporatism for its believability and narrative rationality. With regards to the first prong, narrative coherence, corporatism's narrative undoubtedly 'hangs together'. First, the plotline is consistent: there are Gesellschaft communities and the more harmonious Gemeinschaft variant with elites required to manage the former to be more like the latter. Second, there is enough detail to the narrative because different racial groups and the ruling elite are all identifiable. Third, all the characters in the story behave in a reasonable manner as history is presented to 
show that the races did have tension that spilled over into violence in the 1950s and 1960s and PAP rule has resolved or at least managed such differences. Fourth and finally, there certainly are no unrealistic surprises at the end; the system coheres with empirical reality thus far, as harmony has prevailed and economic prosperity has by and large been attained.

However, with regard to the second prong of the fork, narrative fidelity, the corporatist narrative and corporatist governance can only be preserved if society at large believes in the relevance and significance of this narrative, especially in the verity of its racial divisions, and that these divisions require elite management. Paradoxically, the narrative of governing through difference-predicated on the management of ineliminable differences - is becoming defunct simply because those very racial differences are dissolving with the development of an emerging Singaporean-ness. It is this development of commonality between Singaporeans, despite the continued reinforcement of the social boundaries of race in daily life, which threatens the tightly woven internal narrative logic of corporatism and the virtuous/vicious cycle. In effect, reality is moving slowly away from the narrative that is trying to make sense of it.

Both quantitative and qualitative data presented in the previous section suggest that the fidelity of the corporatist narrative has disintegrated because the five dimensions of fact, relevance, consequence, consistency and the transcendent issue have all been disrupted. With regard to fact, the values in the corporatist narrative are called into question as emerging Singaporean-ness challenges the prescription that society is divided and requires elite neutral management. For the second dimension of relevance, experiencing the foreign disrupts a key component of the corporatist narrative where society is framed as racially divided. Tension between the foreign and the local has displaced tension between the races. As for consequence, Singaporean-ness erodes the value of having race managed in spheres such as housing, education, politics and welfare. As for the fourth dimension of consistency, corporatism may be a victim of its own success. As few Singaporeans would have had first-hand experience of the race riots of the 1950s and 1960s, corporatism's narrative is far removed from current lived experience. Finally, considering the fifth dimension, the transcendent issue of corporatism as a basis for ideal conduct is fading because it fails to resonate with reality on the ground or offer a prescription for further action. 


\section{Conclusion: Corporatism at a Crossroads}

The above-mentioned data, especially the empirical studies, raise interesting questions when juxtaposed with the official government position on national identity. In this regard, the Singapore government has seemingly been eager to devalue and underrate such evidence by consistently emphasizing that race is a potential fault line, and that national identity is not well-established. In effect, this could be interpreted as an attempt to repair the damage done to narrative rationality by the changes in the makeup of Singapore's population brought about by liberal immigration policies as discussed previously. For instance, in his 2009 National Day rally speech, Prime Minister Lee Hsien Loong took pains to stress that 'the most visceral and dangerous fault line [for Singapore] is race and religion. ${ }^{24}$ More recently, this position was reiterated by the then Senior Minister of State for Foreign Affairs, Zainul Abidin Rasheed, who maintained that 'we have witnessed a widening of racial and religious fault-lines...Singapore's current level of harmony is not a natural state...it is always a work-in-progress. ${ }^{25}$ Such statements emphasizing the precariousness of inter-communal relations are often supported with the recounting of incidents that betray a confirmatory bias, a situation made apparent due in part to the contradictory results of the surveys pertaining to race relations in the city-state. ${ }^{26}$ Overall, the government's position with regards to inter-communal relations is unsurprising, considering the corporatist system of governing through difference, which would abhor the awakening and expression of intercommunal unity.

From the governing elite's point of view, if this new unity is not addressed, the corporatist narrative and system may be threatened. As such, in recent years, there has been a drive by the government to manage inter-communal unity while preserving the racial divisions required for corporatism. Two programs that illustrate this strategy are the establishment of Inter-Racial and Religious Confidence Circles (IRCCs) and re-emphasizing of the National Education Programme (NE) for school children. IRCCs, in particular, were created in order to promote intercommunal harmony alongside multiracialism. As noted by former Prime Minister Goh Chok Tong, 'the primary objective is to get our irrational fears off our chest, and get to know each other better. ${ }^{127}$ Government officials hope that IRCCs will permit religious and community leaders to build personal trust, increase confidence and foster a mutual rapport that could be useful in addressing racial and religious problems on the 
ground. Thus, IRCCs do not attempt to remove the differences created by multiculturalism in Singapore. Instead, it is an attempt to perpetuate the corporatist system by both reiterating racial divisions and emphasizing the need for the government as neutral arbiter of inter-racial tension.

To supplement the IRCCs, the importance of the National Education Programme as a tool to transmit Singaporean values across the CMIO categories has been given new impetus. To achieve this objective, the education programme has been built around the following six messages (Tan and Wan 2003: 5):

1. Singapore is our homeland. This is where we belong. We want to keep our heritage and way of life.

2. We must preserve racial and religious harmony. Though many races, religions, languages and cultures, we pursue one destiny.

3. We must uphold meritocracy and prevent corruption. This provides opportunity for all according to their ability and effort.

4. No one owes Singapore a living. We must find our own way to survive and prosper.

5. We must defend Singapore. No one else is responsible for our security and well-being.

6. We have confidence in the future. United, determined, and well prepared, we shall build a bright future for ourselves

Similar to the IRCCs, NE maintains the corporatist structure by reemphasizing both racial differences and the precariousness of harmony (message 2) while acknowledging some form of inter-communal unity (message 1). Regardless, there is no attempt to remove the CMIO distinctions and NE's overall thrust is the message that Singapore is racially divided and government stewardship is necessary to sustain harmony.

Admittedly, these programs may appear to suggest a shift in focus away from earlier policies emphasizing racial distinctiveness towards policies that will increase civil commonality among the groups. However, while these programmes may attempt to manage solidarity, it is notable they do not deal with the crux of the issue: the citizenry is still viewed as fractious and divided and thus requires an enlightened ruling elite to manage it. On that account, they should not be viewed as an attempt to supplant either inter-racial difference or corporatism. The introduction of these programmes should instead be viewed as a strategy, carefully calibrated, to accommodate unity so as to paradoxically safeguard both racial difference and the integrity of the corporatist system. ${ }^{28}$ The most recent example of this balancing act may be found in the PAP's manifesto for the 2011 parliamentary elections. In the mani- 
festo, the ruling party pledges to 'deepen the trust among the various races and religions' while also strengthening 'our common identity with each new generation of Singaporeans' ${ }^{29}$

Interestingly, an alternative and obvious course of action would be for the government to embrace the development of Singaporean-ness. This not as yet adopted strategy, amounting to a volte-face with regards to current rhetoric about the state of race relations in Singapore, could be a viable face-saving option. With such an approach, the government could both acknowledge growing Singaporean-ness, and claim it as a product of the government's determined efforts at nation-building. Consequently, as opposed to denying the presence of Singaporeanness, proclamations can be made that Singapore has truly become, as recited in the national pledge, 'one united people regardless of race and religion'. Unfortunately for the government, this alternative strategy would require tremendous policy renovation and political will. By accepting unity, the policies and programmes discussed above, which were arguably put in place to maintain corporatism, would have to be removed. Hence, public housing policy, education policy with regard to the teaching of the mother-tongue and electoral policy would have to be adjusted as they can no longer be justified as necessary instruments for inter-communal harmony. It is unclear if there is the political will and stamina for such an exercise. ${ }^{30}$ At present, it would appear that this alternative course of action continues to be unacceptable with the official position resolutely framing Singapore as 'a nation in the making... not a reality', while also understanding the phrase pertaining to national unity in the pledge as an 'aspiration'. ${ }^{31}$

It remains to be seen whether both the corporatist narrative and corporatism as a form of governance can be perpetuated indefinitely with the current strategy of accommodating unity to maintain difference and the fidelity of corporatism. Nevertheless, if inter-communal unity continues to develop apace, the alternative option of embracing unity, regardless of the bureaucratic energy it will expend and the political cost it may entail, may become the only viable option.

Norman Vasu is a Senior Fellow and Deputy Head of the Centre of Excellence for National Security (CENS), S. Rajaratnam School of International Studies (RSIS), Nanyang Technological University, Singapore. Damien D. Cheong is a Research Fellow at the Centre of Excellence for National Security (CENS), S. Rajaratnam School of International Studies (RSIS), Nanyang Technological University, Singapore. 


\section{NOTES}

1 The Singapore Story is a euphemism for the official history of Singapore.

2 The two specific communal incidents employed in the official historical narrative are the 1950 Maria Hertogh Riots and the 1964 Prophet Muhammad Birthday Riots. For a more detailed discussion of these incidents, see Leifer (1964) and Narayanan (2004).

3 For the contemporary usage in economic management, see Schmitter (1974). For the older conceptual use, see Wiarda (1981) and Williamson (1989).

4 Speech by Mr Wong Kan Seng, DPM and Minister for Home Affairs, and MP for Bishan-Toa Payoh GRC at the 44th Bishan East National Day Dinner, 1 August 2009. Available from: http://www.singaporeunited.sg/cep/index.php/News-Room/ The-single-most-important-principle-in-our-approach-is-to-build-common-spaces, accessed 25 July 2011.

5 Vanessa Jalleh, 'Double-barrelled Race Option to take effect on Jan 1', Straits Times, 30 December, 2010.

6 'Racial Harmony Day', Ministry of Education, Singapore. Available from: http:// www.ne.edu.sg/core_events.htm\#rd, accessed 14 February 2011.

7 Ministry of Foreign Affairs, 'MFA Press Statement: MFA's Response to the Press Statement of Mr Githu Muigai, UN special rapporteur on contemporary forms of racism, racial discrimination, xenophobia and related intolerance, 28 April, 2010'. Available from: http://www.mfa.gov.sg/content/mfa/media_centre/press_room/ pr/2010/201004/press_20100428.printable.html?status=1, accessed 25 July 2011.

8 Statement by Mr. Saravenan Tanapal, delegate to the 65th session of the United Nations General Assembly on agenda item 66, on elimination of racism, racial discrimination, xenophobia and related tolerance, third committee, 3 November 2010. Available from: http://app.mfa.gov.sg/pr/read_content.asp?View,15399, accessed 25 July 2011.

9 Information Division, 1988, Group Representation Constituencies: A Summary of the Report of the Select Committee, Singapore Ministry of Communications and Information, p. 8.

10 As expressed by MENDAKI, its raison d'être is 'to navigate, empower and position the Malay/Muslim community at the forefront of excellence'.

11 See Keng Swee Goh and the Education Study Team 1979, 'Report on the Ministry of Education 1978', Singapore: Ministry of Education, p. v.

12 National Day Rally Speech (English) by Prime Minister Lee Hsien Loong on 29 August 2010. Available from: http://www.pmo.gov.sg/content/pmosite/mediacentre/ speechesninterviews/primeminister/2010/August/national_day_rallyspeecheng lishbyprimeministerleehsienloongon29a.html, accessed 10 January 2011; 'Entry of Hongkongers won't upset Racial Mix,' Straits Times, 21 August 1989; Bellows 1990: 203.

13 Janadas Devan, 'When in Singapore, act like a S'porean', Straits Times, 22 May 2012.

14 Ministry of Manpower, Employment of Singapore Citizens, Permanent Residents and Foreigners, 1997-2006. Available from: http://www.mom.gov.sg/Publications/ mrsd_employment_SC_PR_foreigners_1997-2006.pdf, accessed 10 January 2011.

15 The Singaporean government appears undecided whether foreign middle and upper management immigrants should be referred to as 'foreign talent' or 'global talent', though both interestingly imply the converse 'local stupid'. For recent use of 'foreign talent', see Secretary-General of the National Trades Union Congress and Minister in the Prime Minister's Office Lim Swee Say's statements in Andrea Tan and Shamim Adam, 'Singapore Unions Propose Foreign Talent Limits, Labor 
Chief Says', Bloomberg, 2 June 2011. Available from: http://www.businessweek. com/news/2011-06-02/ singapore-unions-propose-foreign-talent-limits-labor-chiefsays.html, accessed 5 July 2011. For 'global talent', see International Manpower Division, Factsheet: Study on Relocation Practices for Incoming Global Talent to Singapore (Singapore: Ministry of Manpower, February 2011).

16 Tan Dawn Wei, 'The "Them and Us" Divide', Straits Times, 12 October 2008; Jeremy Au Yeong, Lynn Lee, and Keith Lin, 'Crossing the Them-and-Us Divide', Straits Times, 10 November 2007.

17 Chia Sue-Ann and Leslie Koh, 'New Citizens Make Up Half Our Olympic Team', Straits Times, 18 August 2008.

18 Tan Dawn Wei, 'The Olympic Passport', Straits Times, 24 August 2008.

19 'Immigrants and nation-building in S'pore', The Straits Times, 10 August 2012.

20 Seah Chiang Nee, 'Sports Highlight the Growing Ire', The Star Online, 13 June 2009.

21 Li Xueying, 'New Citizens, Influx of Foreigners Worry Tampines Residents', Straits Times, 21 February 2011.

22 Teo Cheng Wee and Robin Chan, 'PAP Salvo Targets Workers' Party "Star" Chen', Straits Times, 19 April 2011.

23 Teh Joo Lin and Cheryl Lim, 'Stand for Election? "Ensure Male Candidates do NS First",' Straits Times, 3 May 2011.

24 Transcript of Prime Minister Lee Hsien Loong's National Day Rally Speech 2009 on 16 August 2009. Available from: http://www.pmo.gov.sg/content/pmosite/ mediacentre/speechesninterviews/primeminister/2009/August/national_day_r allyspeech2009part3racialreligiousharmony.html, accessed 10 January 2011.

25 Zainul Abidin Rasheed, 'Managing Social, Cultural and Religious Pluralism and Diversity - The Singapore Experience', 22 June 2010. Available from: http:/ /www. singaporeunited.sg/cep/index.php/Our-News/Managing-social-cultural-and-religious-pluralism-and-diversity-the-Singapore-experience, accessed 11 January 2011.

26 Previous issues cited include the charging of three bloggers under the Sedition Act for making seditious and inflammatory racist remarks on the internet in 2005; an incident where a senior civil servant revealed his Chinese mother's unwillingness to enter an elevator with Malays; and the tension between a Chinese and Malay family competing for the use of public space in a housing board estate. See Chong Chee Kin, 'Racist Bloggers Jailed', Straits Times, 8 October 2005; 'Forge Closer Ethnic Ties, Tackle Irrational Fears', Straits Times, 30 January 2002; Prime Minister Lee Hsien Loong's National Day Rally Speech 2009 on 16 August 2009.

27 Cited in National Security Coordination Centre, The Fight against Terror: Singapore's National Security Strategy. Singapore: National Security Coordination Centre, 2004, p. 65.

28 Of course (as highlighted by an anonymous reviewer of this article), another option for the government to preserve the corporatist system would be to position itself as the neutral arbiter for a new social cleavage - one between Singaporeans and the new immigrants. This however would be a difficult and dangerous strategy for the government: difficult, as it would be hard to present itself as a neutral arbiter since its pro-immigration policies have led to the problem in the first place; dangerous, as it may scuttle the government's pro-immigration policies since the simple response to the tension is to be pro-Singaporean and reduce immigration.

29 While the document also pledges to 'help new Singaporeans integrate into our society and contribute actively', it does not mention whether this integration and contribution is towards wider Singaporean society or the corporatist system. See PAP Manifesto 2011, Securing our Future Together. Singapore: People's Action Party, p. 11. 
30 During the 2011 presidential elections, only one candidate-Tan Cheng Bock, a former PAP parliamentarian-appeared to perhaps recognize the end of the corporatist system by maintaining that Singapore has to 'go back to the drawing board, go back and redo the whole [multiracialism] programme again'. He argued that Singapore should begin by merging racial self-help groups as a 'poor Singaporean, poor Malay Singaporean, is the same Singaporean. We should look at it at a national level now, no more at a racial level'. See Andrea Ong and Leonard Lim, 'Tan Cheng Bock Pledges to Promote Multiracialism', Straits Times, 18 August 2011; Alicia Wong, 'Merge EthnicBased Self-Help Groups: Tan Cheng Bock', Yahoo! News Singapore, 17 August 2011. Available from: http://sg.news.yahoo.com/blogs/singaporescene/merge-ethnicbased-self-help-groups-tan-cheng-113752142.html, accessed 16 September 2011.

31 Elgin Toh, 'MM Lee: You Must Want to Die for Each Other', Straits Times, 21 January 2011; May Wong, 'Govt Accountable in Actions, has Worked towards Non-discrimination', Channel NewsAsia, 19 August 2009; reproduced in United Nations Public Administration Network, 24 August 2009. Available from: http://www.unpan. org/PublicAdministrationNews/tabid/115/mctl/ArticleView/ModuleID/1467/ articleId/19825/default.aspx, accessed 20 August 2013.

\section{REFERENCES}

Barth, F. (Ed.) 1969. Ethnic Groups and Boundaries: The Social Organization of Culture Difference. Boston, MA: Little, Brown and Company.

Bellows, T.J. 1990. 'Singapore in 1989: Progress in a Search for Roots'. Asian Survey 30 (2): 201-209.

Brown, D. 1997. The State and Ethnic Politics in South-East Asia. London and New York: Routledge.

Case, W. 2011. 'Executive Accountability in Southeast Asia: The Role of Legislatures in New Democracies and under Electoral Authoritarianism'. Policy Studies 57: xi- 64.

Chan, D. 2002. 'Attitudes on Race and Religion: Survey on Social Attitudes of Singaporeans (SAS) 2001'. Singapore: Ministry of Community Development and Sport.

Chin, Y., and N. Vasu 2007. 'The Ties that Bind and Blind: A Report on Inter-racial and Inter-religious Relations in Singapore'. Singapore: S. Rajaratnam School of International Studies.

Choi, A. 1999. 'Press Coverage of a Social Problem in Singapore: An Analysis of Content, Modes and Styles of Communication'. Asian Journal of Communication 9 (1): 129-147.

Chua, B. H. 1995. Communitarian Ideology and Democracy in Singapore. London: Routledge.

Chua, B. H. 2003. 'Multiculturalism in Singapore: An Instrument of Social Control'. Race $\mathcal{E}$ Class 44 (3): 58-77.

Chua, B. H. 2006. 'Multiracialism as Official Policy: A Critique of the Management of Difference in Singapore'. Paper presented at the workshop, 'Learning from London: Exploring Social Resilience in Singapore', Regent Hotel, Singapore, July 28.

Chua, B. H. 2007. 'Political Culturalism, Representation and the People's Action Party of Singapore'. Democratization 14 (5): 911-927.

Dainton, M. and E. D. Zelly 2005. Applying Communication Theory for Professional Life: A Practical Introduction. Thousand Oaks, CA: Sage Publications.

Dautenhahn, K. 2002. 'The Origins of Narratives: In Search of the Transactional Format of Narratives in Humans and other Social Animals'. International Journal of Cognition and Technology 1 (1): 97-123. 
Norman Vasu and Damien D. Cheong

Fisher, W. 1987. Human Communication as Narration: Toward a Philosophy of Reason, Value and Action. Columbia, SC: University of South Carolina Press.

Fukuyama, F. 1995. 'The Primacy of Culture'. Journal of Democracy 6 (1): 7-14.

Halverson, J. R., H. L. Goodall, Jr. and S. R. Corman 2011. Master Narratives of Islamist Extremism. New York: Palgrave Macmillan.

Koh, E. 2010. Singapore Stories: Language, Class, and the Chinese of Singapore, 1945-2000. Amherst, NY: Cambria Press.

Leifer, M. 1964. 'Communal Violence in Singapore'. Asian Survey 4 (10): 1115-1121.

Low, L. 2001. 'The Singapore Developmental State in the New Economy and Polity'. The Pacific Review 14 (3): 411-444.

MacDougall, J. A. 1976. 'Birth of a Nation: National Identification in Singapore'. Asian Survey 16 (6): 510-524.

Means, G. P. 1998. 'Soft Authoritarianism in Singapore and Malaysia'. In Larry Diamond and Marc F. Plattner (Eds.), Democracy in East Asia, pp. 96-110. London: The Johns Hopkins University Press.

Mutalib, H. 2002. 'Constitutional-electoral Reforms and Politics in Singapore'. Legislative Studies Quarterly 27 (4): 659-672.

Narayanan, G. 2004. 'The Political History of Ethnic Relations in Singapore'. In Lai Ah Eng (Ed.), Beyond Rituals and Riots: Ethnic Pluralism and Social Cohesion in Singapore, pp. 41 - 61. Singapore: Eastern Universities Press.

Ooi, G. L., E. R. Tan and K. C. Soh 2002. The Study of Ethnicity, National Identity and Sense of Rootedness in Singapore. Singapore: Institute of Policy Studies.

Panitch, L. 1980. 'Recent Theorizations of Corporatism: Reflections on a Growth Industry'. The British Journal of Sociology 31 (2): 159-187.

Read, Stephen J., and L. C. Miller 1995. 'Stories are fundamental to meaning and memory: For social creatures, could it be otherwise?' In R. S. Wyer (Ed.) Knowledge and Memory: the Real Story, pp. 139 - 152. Mahwah, NJ: Lawrence Erlbaum Associates.

Schmitter, P. C. 1974. 'Still the Century of Corporatism?' The Review of Politics 36 (1): 85-131.

Schrag, R. L. 1991. 'Narrative Rationality and First Stories: Pedagogical Implications for Children's Television'. Communication Education 40 (4): 313-324.

Schwartzman, S. 1977. 'Back to Weber: Corporatism and Patrimonialism in the Seventies'. In J. M. Malloy (Ed.), Authoritarianism and Corporatism in Latin America, pp. 89-106. Pittsburgh: University of Pittsburgh Press.

Tan, A., and R. Wan, 2003. 'Introduction to National Education in Singapore'. In Steven Tan Kwang San and Goh Chor Boon (Eds.), Securing Our Future: Sourcebook for $\mathrm{Na}$ tional Education Ideas and Strategies for Secondary Schools and Junior Colleges. Singapore: Prentice Hall, Pearson Education Asia Pte. Ltd.: 3-6.

Tan, E. S., and G. Koh 2010. Citizens and the Nation: National Orientations of Singaporeans Survey. Singapore: National University of Singapore.

Vasu, N. 2012. 'Governance through Difference in Singapore: Corporatism's Composition, Characteristics and Complications'. Asian Survey 52 (4): 734-753.

Wiarda, H. J. 1981. Corporatism and National Development in Latin America. Boulder, CO: Westview Press.

Williamson, P. J. 1989. Corporatism in Perspective: An Introductory Guide to Corporatist Theory. London: Sage. 